International Journal of STEM Education for Sustainability, Vol 2, No.1, 2022, pp. 45-52

e-ISSN 2798-5091. DOI. 10.53889/ijses.v2i1.33

\title{
Indonesian Students' Scientific Literacy in Islamic Junior High School
}

Submitted 13 September 2021 Revised 26 October 2021 Accepted 1 November 2021

\author{
Munasprianto Ramli ${ }^{1 *}$, Baiq Hana Susanti², Media Putri Yohana ${ }^{3}$ \\ ${ }^{1,2,3}$ Faculty of Tarbiya and Teaching Sciences, Universitas Islam Negeri Syarif Hidayatullah Jakarta, \\ Tangerang Selatan, Indonesia \\ Corresponding email:*munasprianto.ramli@uinjkt.ac.id
}

\begin{abstract}
Scientific literacy is one of the main and key aspects of facing various challenges in the 21st century. Building students' scientific literacy does not mean making every student a future scientist. However, this is more about building their knowledge of science and technology to play a role in making choices that impact the survival of life today and in the future. This study aimed to analyze the scientific literacy skills of Islamic Junior High School students in Indonesia by using PISA questions from the previous year and finding out their perceptions of PISA academic literacy questions. This study used a sequential explanatory research method with a mixed quantitative and qualitative approach. A total of 150 students from eight Islamic Junior High Schools in West Sumatra and DKI Jakarta Provinces in Indonesia were selected using a purposeful sampling technique. The instruments used are scientific literacy tests to collect quantitative data, interview guides, and open questionnaires for qualitative data. The quantitative data obtained were analyzed by descriptive statistics, while the qualitative data were analyzed by thematic analysis. The results show that the science literacy score of Indonesian Students in Islamic Junior High schools value of Islamic Junior High School students is lower than the average value of the OECD countries and the United States. Then, the students also thought that the scientific literacy questions tested were difficult because they rarely got similar questions. This results also suggest that several factors cause the low literacy scores of Islamic junior high school students, namely their lack of habit of working on similar questions, the limited number of teachers in giving questions that promote critical and analytical thinking skills and the low desire of students to read and explore knowledge other than what they get in school.
\end{abstract}

Keywords: Scientific literacy, Islamic Junior High School Students, Indonesia, PISA

\section{INTRODUCTION}

Advances in science and technology have not only caused humans to be free from challenges in this digital era. Various challenges threaten human survival in the 21st century. Call it the availability of clean water and insufficient food, the emergence of new types of diseases and viruses, and the need for renewable energy to replace fossil energy resources. Scientific literacy skills then become the main and key aspect of facing these various challenges.

Building millennial scientific literacy does not mean making every student a future scientist. However, this is more about building their knowledge of science and technology to play a role in making choices that impact the survival of life today and in the future. Then, as global citizens, they are also required to understand various scientific issues closely related to social problems to contribute to society and the environment. 
Several tests and evaluations are carried out to determine the scientific literacy ability, one of which is PISA (Programme of International Students Assessment) issued by the Organization for Economic Co-operation and Development (OECD). PISA tests the skills and knowledge of fifteen-year-old students in the fields of mathematics (mathematic literacy), reading (reading literacy), and science (science literacy). In 2015, 72 countries took part in the PISA test focusing on scientific literacy, including Indonesia (OECD 2016).

Indonesia's participation in PISA is nothing new. Indonesia has participated in this activity since the emergence of the first PISA program in 2000. Unfortunately, the results shown by Indonesian students selected by the random sampling method were very disappointing. Based on PISA results in the last three periods, Indonesia still gets below average results. In 2009 Indonesia was ranked fifth from the bottom, with an average score of 383 . Then in 2012, there was a decline in ranking, which was ranked second from the bottom and the average score decreased by one point to 382 .

Furthermore, the results of PISA scientific literacy in 2015 showed Indonesia occupies the 64th position out of 72 countries that participated in the activity with a score of 401 . Although the average value of Indonesia's scientific literacy skills increased in 2015, it is still far below the average score of all students, which is 490. Meanwhile, in 2018, Indonesia was ranked 74th among 79 countries, with 396 (OECD, 2016).

The PISA test results for the last three periods seem to indicate that the scientific literacy of Indonesian students is still relatively low. Unfortunately, the available data do not provide a comprehensive picture and publication on Islamic students' scientific literacy is very limited. The sample selection and the number of samples tested in Indonesia and which students from public schools and Islamic schools were sampled were never presented clearly. This gap can be used as a foothold to carry out studies and research, which attracts researchers to conduct studies related to the scientific literacy skills of Islamic junior high school students in Indonesia.

This topic will be an important and interesting part of the study because research must be current and fill the gap due to limited studies and information related to topics in the Muslim community. Besides that, this research is expected to have added value, for example, the contribution of information and knowledge related to topics that have never been published before, namely the scientific literacy ability of Islamic schools Tsanawiyah students in the country assessed based on the framework issued by PISA.

The term scientific literacy has been used in science education research for nearly five decades. The term first appeared in print when Paul Dehart Hurd published his article Scientific Literacy: Meaning for American Schools in 1958 (Bybee, 1997; DeBoer, 2000; Laugksch, 
2000; Holbrook and Rannikmae, 2007). P. Hurd (1958) defines scientific literacy as understanding science and its application in social experience.

Since Hurd introduced the term scientific literacy, several scholars have reviewed and proposed definitions of scientific literacy. Agin (1974) proposed that scientific literacy is an individual's ability to understand scientific products and processes and how science and social activities are interrelated and interrelated in terms of concepts, methods, and applications. Accordingly, the National Academy of Sciences (1995) defines scientific literacy as knowledge and understanding of scientific concepts and processes necessary for personal decision making, participation in civic and cultural affairs, and economic productivity) suggests that scientific literacy, in a narrow sense, is the ability to read and write scientific publications. These various definitions indicate that many scholars have attempted to define the term scientific literacy; however, there is no universally accepted definition (DeBoer, 2000). Students should be able to apply scientific principles to examine evidence and evaluate assertions about the world around them, according to all of these definitions (Shaffer et al, 2019).

Despite the differences in the definition of scientific literacy, experts today believe that scientific literacy is one of the main goals of science education. Roth and Baton (2004) argue that science educators and policymakers agree that scientific literacy is important for educational success.

The main idea of viewing scientific literacy as an educational goal is to educate students about science to be relevant to their daily lives. In other words, science teachers must help students to understand scientific phenomena that occur in everyday life. It implies that science education is for all students; it does not aim to produce scientists and engineers but rather to produce scientifically literate citizens. It means that science education makes science accessible to all students, whether they become scientists or not. Bybee and Ben-Zvi (1998) suggest that students should be taught about inquiry and the scientific method from an early age. Furthermore, Hodson (2000) suggests that science teachers should make science accessible by exploring what they teach, whom they teach, and the ultimate goal of teaching a given material.

Given the importance of science literacy, the Organization for Economic Cooperation and Development (OECD) OECD organizes student literacy assessments through the Program for International Student Assessment (PISA). PISA is a fairly unique standardized test. The material tested is not directly related to the school curriculum. OECD (2006) revealed that PISA is designed to determine the extent to which students can apply their knowledge to real-life situations. PISA focuses on one subject during each assessment year, whereas PISA 2015 focuses on the scientific literacy domain. 
To this day, several studies have examined education policy on the effects of PISA since it was first introduced in 2000. These studies have shown that the public and governments of several countries respond actively to PISA results. In response to widely considered poor PISA results, the French government reformed the education system and primary school curriculum (Baird et al., 2011; Dobbins and Martens, 2012). Similarly, the negative results of the PISA test motivated the German government to change their education system (Knodel et al., 2013; Grek, 2009) and introduce new national education standards (Neuman et al., 2010). PISA results prompted the Norwegian government to introduce a national quality assessment system (NKVS) in 2004 and a national curriculum for knowledge promotion in 2016 (Baird et al., 2011). In Canada, PISA's impact motivates federal and provincial governments to evaluate government investment in education and measure Canada's competitiveness in the emerging workforce (Knighton et al., 2010).

\section{METHOD}

The method used in this research is a sequential explanatory research method with a mixed quantitative and qualitative approach. The mixed research method carried out in this study is explanatory sequential, which is a mixed method that is interesting for individuals with a strong quantitative background to a qualitative approach (mixed methods). Explanatory sequential research involves a two-phase project in which the researcher collects quantitative data in the first phase, analyzes the results, and then uses the results of the first phase to plan the second phase (Creswell \& Creswell, 2018). This design aims to help qualitative data explain in detail the initial quantitative results. A simple description of the explanatory sequential method used can be seen from the flowchart image below.

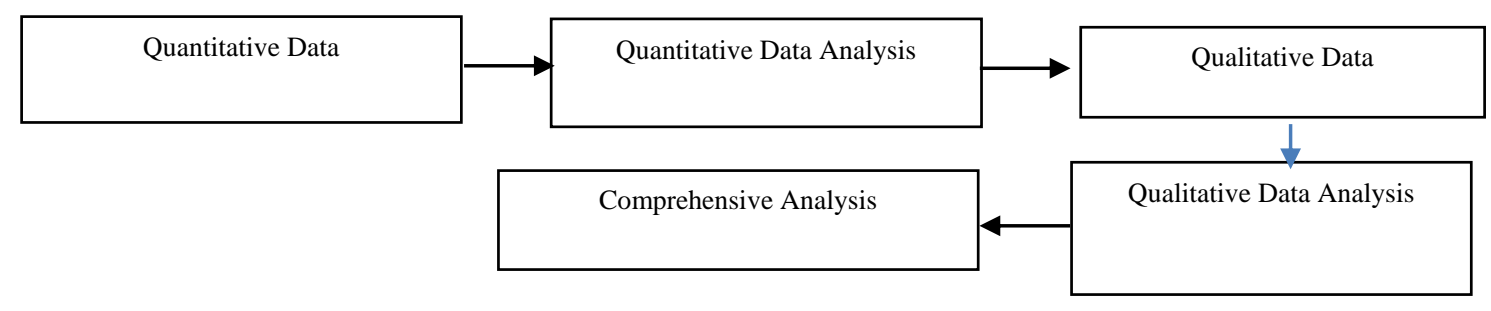

Figure 1. Explanatory sequential research flow to be carried out

Quantitative data was obtained by distributing instruments in a scientific literacy test to 150 students of 7 Islamic Junior High Schools (Islamic schools Tsanawiyah) in the Provinces of West Sumatra and DKI Jakarta, Indonesia. The subjects of this study were selected using purposive sampling and selected as the research sample. The scientific literacy essay instrument used is a question of 30 items adopted from the PISA questions that have been released, and 
then the researchers translate them into Indonesian. To compare Indonesia's ability with developed country students and the OECD average, the researchers used secondary data from the National Center for Education Statistics related to American student scores and the OECD average (National Centre for Education Statistics, 2015). Researchers chose America because data for other countries were not available, so researchers can access only this data. At least this can provide an overview of students' ability in Islamic schools in Indonesia compared to students from developed countries and the OECD average. Considering the pandemic conditions that do not allow data collection by an interview in several places, in addition to interviews, the researcher also provides an open questionnaire to research respondents to find out their perception of PISA scientific literacy.

The quantitative data obtained were analyzed using descriptive statistics. Researchers use Microsoft Excel to analyze the data and present the data in graphs or tables. Then for the qualitative data, the researcher used a thematic analysis approach. Thematic analysis is an analytical process that qualitative encoding information in qualitative research (Ramli, 2014). Braun and Clarke (2006) provide a more comprehensive strategy for thematic analysis. According to Braun and Clarke, thematic analysis can be carried out in 6 steps: familiarizing with the data, initial coding, finding themes, reviewing themes, determining and naming themes, and writing reports. Adapting the strategy of Braun and Clarke (2006) above, the researcher will develop his thematic analysis model for this research. The researcher divides the thematic analysis into three phases, namely, from data to coding, creating themes, and from themes to reports.

\section{RESULTS AND DISCUSSION}

The quantitative data obtained are the scores of 150 students who answered the instrument in a scientific literacy test consisting of 10 discourses and 30 questions. Based on the data obtained, it can be seen that the ability of Islamic schools students is below the average of students in OECD countries, as shown in Figure 2. 


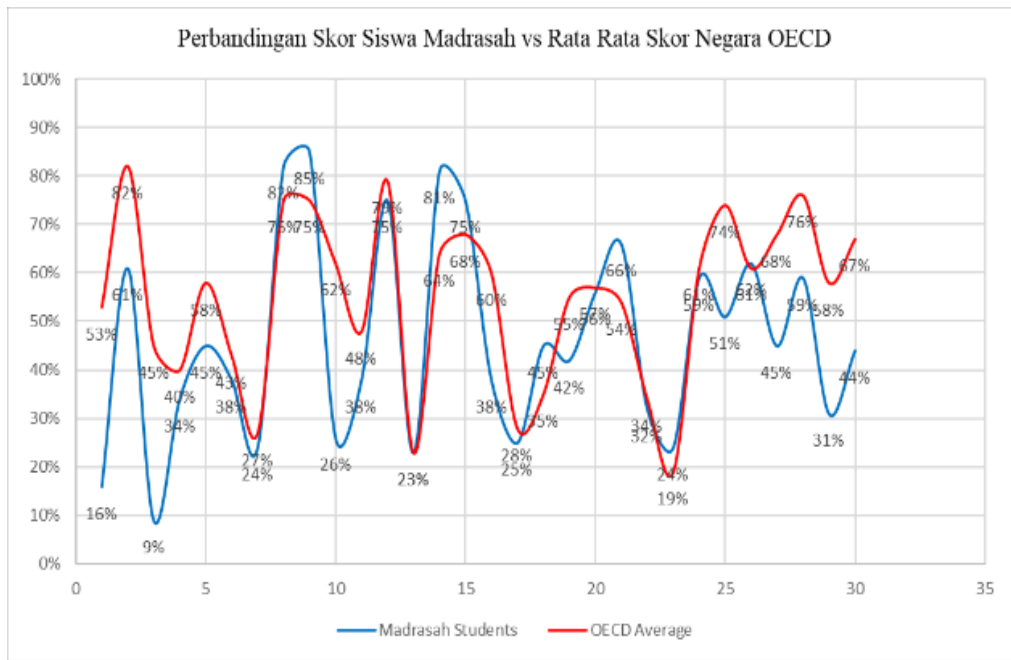

Figure 2. Comparison of Islamic Junior High Schools' student scores vs OECD country average scores

Then, if we compare it with the average American student who answered the similar questions, we will get the following picture.

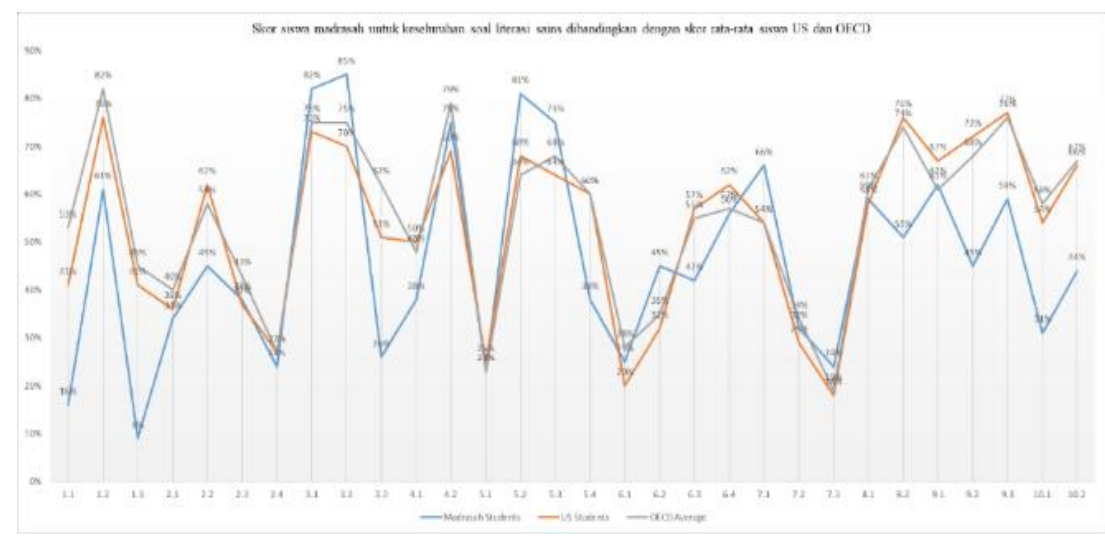

Figure 3. Islamic junior high school students' scores on overall scientific literacy questions compared to U.S. and OECD students' mean scores

From the two graphs above, it can be seen that, in general, the number of Islamic schools students who answered scientific literacy questions was below the score of United States students and the OECD average. However, this does not mean that this value applies to all questions. Several questions show that Islamic schools students have higher scores than OECD students and United States students in the second, third, and sixth discourses.

There are three types of questions in the test: yes and no, multiple-choice, and essay. Researchers tried to compare the scores of multiple-choice essay questions and compare them with the average OECD countries and the United States. From this comparison, a graph is obtained, as shown in Figure 4 below. 


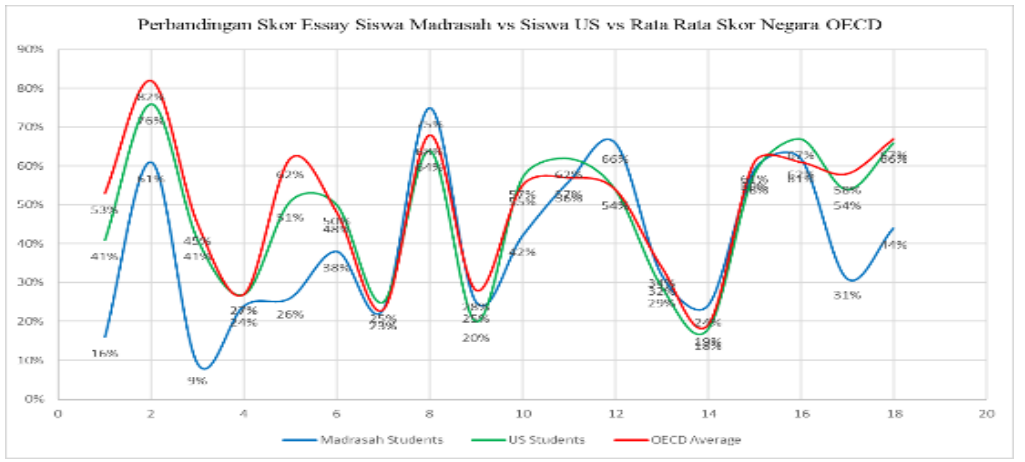

Figure 4. Comparison of essay scores of islamic schools students vs. U.S. students vs. average OECD country scores

From the table above, it can be seen that the ability to answer essay questions for islamic schools students is below the OECD average and the United States. Only for questions number 8 and 12 only where the score of Islamic Schools students are above the OECD and U.S. average

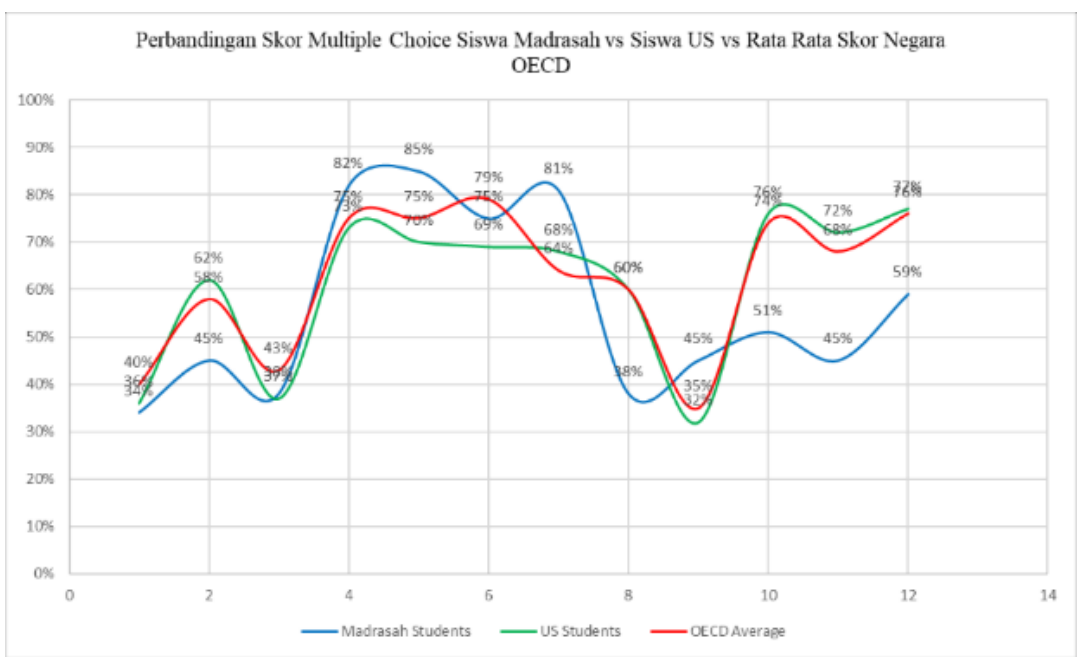

Figure 5. Comparison of multiple-choice scores of islamic schools students vs. U.S. students vs. average OECD country scores

As for the multiple-choice questions, as shown in the graph, the percentage of Islamic schools students who answered questions no. 4,5,7, and 9 were above the U.S. and the OECD average. It shows that Islamic schools students' ability to answer multiple-choice questions is better than answering essay questions. It may be because Islamic schools students are more familiar with multiple-choice questions than essay questions. Overall the scores obtained by the students, if grouped based on the average value, will be obtained in Table 1.

Table 1. Percentage of science literacy scores for Islamic schools Tsanawiyah students 


\begin{tabular}{ll}
\hline Score and Level & $\%$ Students \\
\hline $76 \%-100 \%$ (Level 4) & 1 \\
$51 \%-75 \%($ level 3) & 46 \\
$26 \%-50 \%($ level 2) & 48 \\
$0 \%-25 \%($ level 1) & 4 \\
\hline
\end{tabular}

From Table 1 above, it can be seen that only $1 \%$ of islamic schools students can answer questions with scores above $75 \%$. Most students do not have good scientific literacy skills or are still relatively low. It confirms the report from the OECD based on the results of the PISA test that the scientific literacy ability of Indonesian students is still low (OECD, 2019).

In this study, researchers also investigated the perceptions of Islamic schools students on scientific literacy questions. The researcher looked at how the students saw the questions and the extent to which they had received some questions in class.

Table 2. Students' opinions on the difficulty level of scientific literacy questions

\begin{tabular}{ll}
\hline Students' Opinions on the Difficulty of Science Literacy Questions & Percentage (\%) \\
\hline Easy & 2 \\
Quite Difficult & 49 \\
Difficult & 40 \\
Very Difficult & 9 \\
\hline
\end{tabular}

From Table 2 above, it can be seen that only $2 \%$ consider science literacy questions to be in the easy category. $49 \%$ considered it rather difficult, $40 \%$ considered it difficult, and $9 \%$ considered it difficult. Seeing the students' responses to the level of difficulty of the questions, which 49 stated that they were difficult and very difficult, it is not surprising that the scores obtained were below the OECD average. It means that questions like this are still considered difficult, so they will certainly be overwhelmed in answering them.

Table 3. Students' opinions about teachers having given questions such as the PISA test

\begin{tabular}{ll}
\hline $\begin{array}{l}\text { Experience of students working on similar } \\
\text { questions }\end{array}$ & Percentage \\
\hline Ever & 69 \\
Never & 31 \\
\hline
\end{tabular}

Table 4. Students' opinions on how often teachers give questions like in this test

\begin{tabular}{ll}
\hline Student Opinions About How Often Teachers Give & Percentage \\
Questions Like in This Test & 49 \\
Seldom & 41 \\
Quite Often & 10 \\
Often & 0 \\
Very Often & \\
\hline
\end{tabular}


From the Table 3 and 4 above, it can be seen that almost $70 \%$ of students assume their teacher has given questions in the same format or form in class. However, almost $50 \%$ of them said that their teacher rarely gave similar questions. Only $10 \%$ of students often get similar questions in class. It shows that exposure to questions that prioritize high-order thinking skills affects students' ability to answer similar questions. The less often students are presented with questions that prioritize analytical thinking skills, the more difficult it will be to answer questions like in this scientific literacy test.

The data obtained from interviews and open interviews also support what has been obtained from quantitative data. As presented in table 2, only $2 \%$ of students think that these questions are easy. Some of them find it easy because they like science and like questions that test understanding, as seen from the following excerpt.

"In my opinion, the problem is not difficult, because I am really happy with questions of understanding like this. Usually for science olympiads it's like this, so it's not that hard"

(Interview with students, 3 August 2020)

"I think it is easy. Easy to understand. Maybe because I like reading magazines or reading scientific articles."

(Interview with students, August 4, 2020)

From the two interview excerpts above, it can be seen that the students who think the questions are easy are because they are already familiar with such questions. They are used to it because they have participated in science olympiads. After all, there are also essays with fairly long texts. Then some find it easy because they like scientific articles, so they are exposed to scientific issues that help them answer questions.

Some think this scientific literacy question is difficult because they have a hard time understanding the text and need extra energy and thought in answering the question, as seen from the following interview excerpts and open questionnaires.

"Because all of these test questions must be read carefully and must be focused, and many are also poorly understood"

(student's open questionnaire)

"Because these questions are a bit difficult to understand because we have not fully studied this material. Moreover, you need to read all of them to understand."

(student's open-ended questionnaire)

Looking at what the students have said above, we can draw two things that make them think that the question is rather difficult. The first is because it requires understanding and their reading skills and taking the essence of what they read. It is nothing but shows that our students' skills in understanding the text are still quite low. The second aspect that made it difficult for them was that they had not learned some of the material. It is understandable because testing is not all under the curriculum, as described in the PISA document. However, what is presented 
has been adjusted to the age of the participants. It indicates that our students' interest in and interest in deeper into content outside of school lessons is still quite low.

Similar to the group of students who considered the PISA questions a bit difficult, the group that chose the PISA questions was categorized as difficult and very difficult because they had not studied and were not familiar with questions like this. It can be seen from the following excerpt of an open questionnaire.

"Because there are many questions that I do not understand, and the reading is long, and I do not understand. Maybe it is because I have never answered questions like this before." (student's open-ended questionnaire)

Almost all students who categorize PISA questions are difficult because they are long and difficult to understand. It means that they still do not have good literacy, not only in scientific literacy but also in reading skills. They still cannot get the gist of what is being said or are not used to getting questions like this. It is corroborated by the fact presented in tables 3 and 4 that $31 \%$ of students have never received a similar question, while $69 \%$ have received a question. Of the $69 \%$ percent who stated that they had received science questions that began with text or accompanied by discourse, only $10 \%$ felt that their teachers often gave similar questions that prioritized understanding and high-order thinking skills. So it is not surprising that our students are not familiar with these HOTS questions, as they conveyed during interviews and in open questionnaires;

"I'm not used to things like this, not even ever. The questions given to us are only multiple choice questions and there is no need to read"

(student interview, 3 August)

"I am not used to it. Because I usually work on questions whose material has been studied, this question is answered with material that has not been discussed. The questions that are usually discussed are also questions that are easy and not complicated."

(student's open-ended questionnaire)

From what the students described above, it can be seen that the learning experience will affect the students' ability to answer questions that need understanding. Their unfamiliarity with answering complex questions that require critical and analytical thinking makes it difficult to answer the PISA test. It also means that teachers have not put too much effort into training students with questions that prioritize HOTS. It is also in line with what the students stated: if they were given practice with similar questions in class, they might answer these PISA questions.

"To be able to answer questions like this, we should be taught, explained, experimented" (student's open-ended questionnaire)

"It is better for the teachers to familiarize us with questions like this so that we should get used to it and be able to answer questions like this"

(Student's open-ended questionnaire) 
Apart from the expectation for teachers to familiarize them with questions that hone critical and analytical thinking skills, students also believe that they should hone themselves. The students believe that by reading more diligently and exploring more diligently, they will answer the PISA questions.

"By reading more science materials/books and studying them, I will be able to answer these questions well, because some of the material was not studied"

(Student's open-ended questionnaire)

"I have to read a lot, get to know new terms, learn to read graphs, learn to conclude an experimental step in the text."

(Student's open-ended questionnaire)

From the two quotations above, it can be seen that the student's experience of learning science is still small. Students need to get more coaching related to their scientific literacy skills. Human learners understand that they are still not reading enough, not exploring science. Nevertheless, their awareness alone is certainly not enough. The presence of teachers who are ready to collaborate in building their thinking horizons will be the key to developing scientific literacy. Not teachers who only give fair multiple-choice questions and do not dare to challenge giving HOTS questions that can take their students to explore the universe to build their understanding of the classroom learning experience. It then reinforces what has been conveyed from previous research studies that students' literacy skills will be strongly influenced by teachers, school environments and lesson materials (Ramli et al. 2021, Alivernini \& Manganelli 2015, and Ministry of National Education 2015)

\section{CONCLUSION}

This study aimed to analyze the scientific literacy skills of Islamic Junior High School students in Indonesia by using PISA questions from the previous year and finding out their perceptions of PISA academic literacy questions. Based on the findings, the scientific literacy ability of Islamic schools' students is still quite low. Of the 30 PISA items in the previous year that we gave students, their scores were below the OECD average and American students. Of the 30 questions, Islamic schools' students only outperformed the OECD and American averages in 6 item numbers; the rest were below. Then only $1 \%$ of Indonesian students have high scientific literacy skills.

Then, judging from the students' perceptions of the PISA questions, only $2 \%$ of students thought the questions were easy. The rest considered the questions given to be rather difficult, difficult and very difficult. So it is not too surprising that our scientific literacy scores lag far behind OECD countries.

However, it cannot be regretted if only a few see that scientific literacy questions are easy to conquer because they are unfamiliar with questions like this. $31 \%$ of students stated that they 
never got the questions as tested. Of the $69 \%$ who felt that they had received questions from their teacher, only $10 \%$ stated they were often allowed to work on questions like this.

From what was said by the students, it can be understood that several factors influence their difficulty in conquering the questions of scientific literacy. The first is because they are very rarely exposed to questions like this. The teachers only give multiple-choice questions and those that are following the lesson. Second, teachers have not been optimal in training students with questions that prioritize high-level thinking. Third, their awareness to read and seek knowledge outside of school lessons is also still low, which causes our students' scientific literacy skills to lose to other countries.

\section{ACKNOWLEDGEMENT}

This study was supported by Center for Research and Publication (Puslitpen) LP2M

UIN Syarif Hidayatullah Jakarta (Grant Number Un.01/KPA/1346/2019).

\section{REFERENCES}

Alivernini, and Manganelli, S (2015) Country School and Students Factors associated with extreme levels of science literacy Across 25 Countries Int. J. Sci. Edu. 37 (12) 1992-2012

Baird, J. A., Isaacs, T., Johnson, S., \& Stobart, G. (2011). Policy Effect of PISA. Oxford University Centre for Educational Assessment.

Braun, V. and Clarke, V. (2006) Using thematic Analysis in Psychology. Qualitative Research in Psychology, 3 (2), pp. 77-101.

Bybee, R. W. (1997). Achieving scientific literacy: From purposes to practices. Portsmouth, NH: Heinemann.

Bybee, R. W. and Ben-Zvi, N. (1998). "Science curriculum: transforming goals to practice". In International handbook of science education, Edited by: Fraser, B. J. and Tobin, K. G. 487-498. Dordrecht: Kluwer Academic Publishers.

Creswell, J.W , Creswell J,D (2018) Research Design Qualitative, Quantitative, and Mixed Methods Approaches. California: Sage Publications, inc.

DeBoer, G. E. (2000). Scientific literacy: Another look at its historical and contemporary meanings and its relationship to science education reform. Journal of Research in Science Teaching, 37(6), 582-601.

Dobbins, M., \& Martens, K. (2012). Towards an education approach à la finlandaise? French education policy after PISA. Journal of Education Policy, 27(1), 23-43.

Grek, S. (2009). Governing by numbers: the PISA 'effect' in Europe. Journal of Education Policy, 24(1), 23-37.

Holbrook, J., \& Rannikmae, M. (2007). The Nature of Science Education for Enhancing Scientific Literacy. International Journal of Science Education, 29(11), 1347-1362. 
Hurd, P. D. (1958). Science literacy: Its meaning for American schools. Educational Leadership, 13-16.

Knighton, T., Brochu, P., \& Gluszynski, T. (2010). Measuring Up: Canadian Results of the OECD PISA Study The Performance of Canada's Youth in Reading, Mathematics and Science 2009 First Results for Canadians Aged 15. Ministry of Industry Canada.

Knodel, P., Martens, K., \& Niemann, D. (2013). PISA as an ideational roadmap for policy change: exploring Germany and England in a comparative perspective. Globalisation, Societies and Education, 11(3), 421-441

Laugksch, R. C. (2000). Scientific literacy: A conceptual overview. Science Education, 84(1), 71-94.

National Centre for Education Statistic (2015). PISA Science Literacy Items and Scoring Guides. Available at https://nces.ed.gov/surveys/pisa/pdf/items2_science.pdf

Neumann, K., Fischer, H. E., \& Kauertz, A. (2010). From PISA to Educational Standards: The Impact of Large-Scale Assessments on Education in Germany. International Journal of Science and Mathematics Education, 8(3), 545-563

Ramli, M et al (2021). Assessing islamic junior high schools students' scientific literacy using PISA released items. Journal of Physics Conference Series 1836012068

Shaffer, J.F, Ferguson, J and Denaro K (2019). Use of the Test of Scientific Literacy Skills Reveals That Fundamental Literacy Is an Important Contributor to Scientific Literacy. CBE_-Life Sciences EducationVol. 18, No. 3. 